\title{
Role of Librarians in Child Abuse Sensitization in Obio/Akpor Local Government Area of Rivers State.
}

\author{
Omehia, A . E.(Ph.D) \\ Department of Library and Information science, Ignatius Ajuru University of Education, Port Harcourt, Rivers \\ state
}

\begin{abstract}
The study investigated the "Role of Librarians in Child Abuse Sensitization in Obio/Akpor Local Government Area of Rivers State'. Simple random sampling was used to select 32 librarians (16 males and 16 females) from four libraries in four tertiary institutions (University of Port Harcourt, Rivers State University, Ignatius Ajuru University of Education and Rivers State School of Nursing). The instrument used for data collection was a selfstructured questionnaire titled "Role of Librarians in Child Abuse Sensitization in Obio/Akpor Local Government Area of Rivers State (ROLCAS)". The instrument was structured in four point rating scale of agreement; that is (Strongly Agree, Agree, Disagree, Strongly Disagree). The validity of the instrument was carried out by two research experts in the department of Library and information science in Ignatius Ajuru University of Education. The reliability of the instrument was determined using test- retest method. The result was correlated using Pearson Product Moment Correlation, and yielded a reliability coefficient of 0.93 , which indicated that the instrument was reliable. The gathered data were analyzed using mean and standard deviation and hypotheses was tested at 0.05 level of significance. It was found that flogging/beating, denial of food, hawking, sexual abuse, verbal abuse, denial of books, unpleasant touches among others are forms of child abuse in the society. Also, it was found that disabilities, death of parents, poverty, unemployment, violent parents, low education, social isolation of families, among others are the causes of child abuse. The study also concludes that it is necessary to disseminate research information to social services, promoting awareness of child abuse by recommending novels, enhance supply of child abuse literatures in schools and develop programmes on child abuse and its prevention among others. Finally, it was also found among others that efforts should be made to educate parents and children about child abuse through the promotion of reading culture in the library, improve positive parenting through reading related literature, and provide community based reading activities on preventing child abuse. The study recommends that librarians should contribute to solving the menace of child abuse by the utilization of library holdings for awareness and sensitization.

KEYWORDS: Role, Librarian, Child, Abuse, Sensitization

DOI: $10.7176 / \mathrm{IKM} / 9-5-06$

Publication date:May $31^{\text {st }} 2019$
\end{abstract}

\section{INTRODUCTION}

Child abuse is a widespread phenomenon that has attracted local and global concern. The menace of child abuse is widespread and cuts across cultural, sex, ethnic and religious groups. Child abuse in Africa is a major threat to the achievement of the sustainable development and it has become increasingly topical with a dramatic increase in recognition and an appreciation of the long term harmful effects or the affected population. According to Badoe (2017), an estimated number of 95 million children experience abuse annually, with the highest rates reported in the World Health Organization (W.H.O) African region. Nordqvist (2018) reported that child abuse is a serious problem that resulted in 1,750 child fatalities in the U.S. in 2016.One study has it that in the United States, Child Protective Services (CPS) received 676,000 reports of individuals experiencing abuse or neglect in 2016.Despite this trend, child abusein Nigeria and Africa, has not yet attracted the interest of researcher as there is a paucity of data.

Oloke -Ake (2000) described child abuse as all sort of injustice, abnormalities and inhuman treatment given to the young feeble ones by the adult generation. According to Gupta and Aggarwal (2012) child abuse is doing something or failing to do something that results in harm to a child at risk or harm. Alokan (2010) defined child abuse as any behavior which neglects the child's survival and development needs, causes physical or emotional injury, harassment or subject the child to measures, situations and experiences which interfere with healthy development towards adulthood. In the view of the World Health Organization (WHO)child abuse comprises all form of physical and/or emotional ill-treatment, sexual abuse, neglect or negligent treatment or commercial and 
other exploitation resulting in actual or potential harm to the child's health, survival, development or dignity in the contexts of a relationship of responsibility, trust or power. Child abuse could therefore be seen asany form of physical, emotional and sexual cruelty done to a child that may negatively affects the health and development of a child.

However, the UK government have identified four main categories of child abuse, these are: physical, emotional, sexual and neglect. In other words, child abuse may be differentin forms such as physical, emotional, sexual and neglect. Any of this is detrimental to the health and mental development of a child. Physical abuse of a child is described as those acts of commission by a caregiver that cause actual physical harm or have the potential for harm. This involves non- accidental harming of the child or non accidental physical injuries inflicted upon a child by a person having the care of a child justified as being a form of discipline (W.H.O, 2006). Physical abuse of a child mostly occurs when caregivers or parents dish out anger on a child without being careful of inflicting injuries on the child. Physical abuse leads to illness which may results in hospitalization of the child. Reports from W.H.O (2006), claimed that in nearby Swaziland nearly one-in-five females had experienced physical abuse in their lifetime with nearly one in twenty having experienced abuse that was so severe, that it required medical attention.

Sexual abuse is defined as those acts where a caregiver uses a child for sexual purpose or involves a child in sexual acts. According to National centre for victims of crime (2011), all children are vulnerable to sexual abuse; girls are more likely, to be sexually abused than boys. Sexual abuse of a child is one of the forms of child abuse that is appalling in the modern society. Studies have it that there are diverse cases of sexual abuse of girl children who are not staying with biological parents. That is, children who are not staying with their parent have wide chances of being sexually abused mostly by elderly ones. Also, report shows that sexual abuse of children is a major problem where for up to one-third of adolescent girls, the first sexual experience was had under duress.

Emotional abuse includes the failure of a caregiver to provide an appropriate and supportive environment, and includes acts that have an adverse effect on the emotional health and development of a child. McGrill University Research in Scutti (2015) showed that emotional abuse of a child may be as harmful as physical abuse and neglect, while child abuse often occurs together with other form of maltreatment. Also a child experiences emotional abuse when his/her psychological, emotional or social well-being is continually battered. Emotional abuse arises from acts such as rejection, humiliation, insults, setting unreasonable expectations or restricting opportunities for the child to learn, socialize or explore. Verbal abuses from friends, elders, parents, teachers and peers create a sense of inferiority in a child which may lead to emotional trauma. Neglect refers to the failure of a parent to provide for the development of the child - where the parent is in a position to do so - in one or more of the following areas: health, education, emotional development, nutrition, shelter and safe living conditions. CFCA Resource sheet, (2016) reported that neglect is sometimes as a result of parents or caregivers socioeconomic status, physical and mental disabilities. Neglect occurs when parents or caregivers intentionally or by circumstances do not provide for needs of the child.

Ministry of Social Welfare, Gender and Children's Affairs Sierra Leone (2009) noted that Child Abuse can be perpetrated in a family by a parent, family member, guardian, care giver, by an institution or in a community setting. Child abuse is not confined to any one group or social class, but cuts across all ethnic, religious, social and economic backgrounds. Not only adults abuse children sometimes older children and young people can and do abuse younger children. Child abuse usually occurs in the homes and families. When parents and caregivers are not able to cater for the necessities of their children, it leads to neglect or emotional abuse. As a result of this abuse, child(ren)'s behavior and mood is being shattered. It is well known that, children who are dysfunctional in behavior, act very indifferent from their peers. Therefore, not only does child abuse lead to life threats but it also results in negative change of behavior in children which may put the rest of their lives in jeopardy. The government of Netherlands proposed that children's lives are shaped by their experiences, including what happens in their environment and the types of relationships they have with parents, teachers, and other caregivers.

To deal with the high rate of child abuse, all spheres of the societies and organizations should be fully involved. Library as a major part of the society dealing with information archives, communication and research has substantial contribution to the control and prevention of child abuse. Regarding ways to control child abuse, the Government of Netherlands suggested that teaching future professionals on child abuse and launching a public information campaign against child abuse among others are effective. The government further encouraged educational institution to include the subject of child abuse in the study programmes for future professionals. 
Therefore, librarians in this sense will be resourceful in gathering and arrangement of relevant information for both teaching of child abuse in schools and rendering public information campaign against abuse.

Library is a subset of educational institutions that has in its holdings myriads of vital information for child abuse sensitization. Librarians could enhance the supply and publication of child abuse literatures to schools for campaigns and sensitization. Itsekor (2011) noted that librarians acquire and organize information resources for different categories of users and since they are constantly abreast with the information resources they are always readily available to assist patrons with the required information. They disseminate information resources in a particular subject field and ensure users find their way easily in subject areas that are even relatively new to them. Collection of library materials in the modern times is less about acquiring and hosting and more about negotiating and facilitating access to resources but selecting and describing the information sources offered to users are still for librarians in the $21^{\text {st }}$ century (Brophy, 2007). So, librarians will serve as effective tools in enabling the dissemination and access to research materials for child abuse sensitization especially in secondary school.

In preventing the child abuse cases in the society, there are various measures which have been introduced by the government such as parent support, public information campaign against child abuse, teaching future professionals against child abuse, preventing child pornography, mandatory report code about child abuse among others. Factsheet (2018) stressed that there are protective factors that may help to lower the risk of child abuse, these are nurturing and attachment, knowledge andparenting of child, youth development, parental resilience and social connections. It further categorizes preventive measures into individual prevention efforts, community prevention, organization efforts and national prevention effort.

Individual prevention efforts are ;

- Learn the signs of child abuse and neglect

- Report any concern

- Help a family under stress

- Be an active community member

- Keep your neighborhood safe

Community prevention efforts are:

- Engage communities in child abuse campaigns or sensitization

- Spark conversations with potential community partners

National prevention efforts include:

- Organizing community-based primary prevention programmes and services.

- Building hope centre for children

\section{Purpose of the Study}

The study examined the Role of Librarian in Child Abuse Sensitization in Obi/Akpor Local Government Area of Rivers State

Specifically the study sought to:

1. Identify what constitutes child abuse in Obio/Akpor Local Government Area of Rivers State

2. ascertain the causes of child abuse in Obio/Akpor Local Government Area of Rivers State

3. determine the functions of Librarian in Child Abuse Sensitization in Obio/Akpor Local Government Area of Rivers State

4. identify preventive measures to curb Child Abuse in Obio/Akpor Local Government Area of Rivers State 


\section{Research Questions}

1. What constitutes child abuse in Obio/Akpor Local Government Area of Rivers State?

2. What are the causes of child abuse in Obio/Akpor Local Government Area of Rivers State?

3. What are the functions of Librarian in Child Abuse Sensitization in Obi/Akpor Local Government Area of Rivers State?

4. What are the preventive measures to curb Child Abuse in Obi/Akpor Local Government Area of Rivers State?

\section{Hypothesis}

$\mathbf{H}_{\mathbf{0 1}}$ : There is no significant difference between the mean responses of male and female librarians on the functions of librariansin child abuse sensitization in Obio/Akpor Local Government Area of Rivers State

\section{Methodology.}

The study adopted descriptive survey design. The population of the study comprised of all librarians in tertiary institutions in Obio/Akpor Local Government Area of Rivers State.However, simple random sampling was used to select 32 librarians (16 males and 16 females) from four libraries in four tertiary institutions (University of Port Harcourt, Rivers State University, Ignatius Ajuru University of Education and Rivers State School of Nursing). The instrument used for the study was a questionnaire structured by the researcher based on each of the research questions. The instrument was titled "Role ofLibrariansin Child Abuse Sensitization in Obio/Akpor Local Government Area of Rivers State (ROLCAS)". The instrument was structured in four point rating scale of agreement; that is (Strongly Agree, Agree, Disagree, Strongly Disagree). The validity of the instrument was carried out by two research experts in the department of Library and information science in Ignatius Ajuru University of Education. The reliability of the instrument was determined using test- retest method. Ten copies of the instrument were distributed to population of librarians who were not included in the study on two different occasions. The result was correlated using Pearson Product Moment Correlation, and yielded a reliability coefficient of 0.93 , which indicated that the instrument was reliable. The instrument were administered and collected from the respondents. The gathered data were analyzed using mean and standard deviation and hypotheses was tested using z-test at 0.05 level of significance.

\section{Result and Discussion}

1. What constitutes child abuse in Obio/Akpor Local Government Area of Rivers State?

Table 1: What constitutes abuse of a child in Obio/Akpor Local Government Area of Rivers State?

\begin{tabular}{|c|c|c|c|c|c|c|c|}
\hline \multirow[b]{2}{*}{$\begin{array}{l}\mathrm{S} / \\
\mathrm{N}\end{array}$} & \multirow[b]{2}{*}{ What constitutes child abuse } & \multicolumn{3}{|c|}{ Male librarian $=16$} & \multicolumn{3}{|c|}{ Female librarian $=16$} \\
\hline & & $\bar{x}$ & S.D & Remarks & $\bar{x}$ & S.D & Remarks \\
\hline 1 & Flogging/beating & 3.21 & 0.75 & Agreed & 3.45 & 0.62 & Agreed \\
\hline 2 & Denial of clothes & 3.35 & 0.67 & Agreed & 3.12 & 0.76 & Agreed \\
\hline 3 & Denial of school fees & 3.55 & 0.54 & Agreed & 3.29 & 0.91 & Agreed \\
\hline 4 & Denial of food & 3.47 & 0.62 & Agreed & 3.23 & 0.81 & Agreed \\
\hline 5 & Hawking & 3.10 & 1.02 & Agreed & 3.18 & 0.90 & Agreed \\
\hline 6 & Sexual abuse & 3.34 & 0.79 & Agreed & 3.29 & 0.67 & Agreed \\
\hline 7 & Verbal abuse & 3.41 & 1.10 & Agreed & 3.35 & 0.99 & Agreed \\
\hline 8 & Work in factories & 2.89 & 0.96 & Agreed & 3.32 & 0.87 & Agreed \\
\hline 9 & Denial of books & 3.12 & 0.77 & Agreed & 3.43 & 0.98 & Agreed \\
\hline 10 & Coercion into early marriage & 3.48 & 0.69 & Agreed & 3.56 & 1.08 & Agreed \\
\hline 11 & unpleasant touches & 3.44 & 0.82 & Agreed & 3.34 & 0.78 & Agreed \\
\hline & Grand Mean \& S.D & 3.31 & 0.79 & & 3.32 & 0.85 & \\
\hline
\end{tabular}

Field Survey, 2019 
Table 1 shows what constitutes child abuse in Obio /Akpor Local Government Area of Rivers State. Based on the mean acceptance value of 2.50 , it was found that flogging/beating ( $3.21 \& 3.45)$, denial of clothes $(3.35 \&$ 3.12 ), denial of school fees (3.55 \& 3.29), denial of food (3.47 \& 3.23), hawking (3.10 \& 3.18), sexual abuse (3.34 \& 3.29), verbal abuse (3.41 \& 3.35), work in factories (2.89 \& 3.32), denial of books (3.12 \& 3.43 ), coercion into early marriage ( $3.48 \& 3.56)$, unpleasant touches $(3.44 \& 3.34)$ are what constitutes child abuse in the society. These findings are in line with McGrill University Research in Scutti (2015) which showed that emotional abuse of a child may be as harmful as physical abuse and neglect, while child abuse often occurs together with other form of maltreatment. This is also supported by World Health Organization (2006) which noted that child abuse constitutes diverse actions that may negatively influence the health, emotional and mental development of a child.

Research Questions 2: What are the causes of child abuse in Obio/Akpor Local Government Area of Rivers State?

Table 2: What are the causes child abuses in Obio /Akpor Local Government Area of Rivers State?

\begin{tabular}{llllllll}
\hline & \multicolumn{2}{c}{ Male librarian } & \multicolumn{2}{c}{ Female librarian } \\
S/N & ITEMS & $\overline{\boldsymbol{x}}$ & S.D & Remarks & $\overline{\boldsymbol{x}}$ & S.D & Remarks \\
\hline 1 & Disabilities & 3.59 & 0.80 & Agreed & 3.37 & 0.78 & Agreed \\
2 & Death of parents & 3.60 & 0.94 & Agreed & 3.50 & 0.66 & Agreed \\
3 & Poverty & 3.30 & 1.00 & Agreed & 3.41 & 0.71 & Agreed \\
4 & Unemployment & 3.30 & 1.01 & Agreed & 3.22 & 0.90 & Agreed \\
5 & Drunken parents & 2.90 & 0.91 & Agreed & 2.99 & 0.96 & Agreed \\
6 & Violent parents & 3.44 & 0.80 & Agreed & 3.09 & 0.83 & Agreed \\
7 & Low education & 3.31 & 0.91 & Agreed & 3.30 & 0.70 & Agreed \\
8 & Poor neighborhood & 2.80 & 0.88 & Agreed & 3.00 & 0.86 & Agreed \\
9 & Social isolation of families & 3.68 & 0.91 & Agreed & 3.22 & 0.81 & Agreed \\
10 & Parental stress and distress & 3.06 & 1.07 & Agreed & 3.31 & 1.00 & Agreed \\
& Grand Mean \& S.D & $\mathbf{3 . 3 0}$ & $\mathbf{0 . 9 2}$ & & $\mathbf{3 . 2 4}$ & $\mathbf{0 . 8 2}$ & \\
\hline
\end{tabular}

Field Survey, 2019

Table 2 presents the causes of child abuse in Obio/Akpor Local Government Area of Rivers State.The analyzed mean responses for each item on the table shows that disabilities (3.59 \&3.37), death of parents $(3.60 \& 3.50)$, poverty ( $3.30 \& 3.41)$, unemployment $(3.30 \& 3.22)$, drunken parents ( $2.90 \& 2.99)$, violent parents $(3.44 \&$ 3.09 ), low education (3.31\&3.30), poor neighborhood (2.80 \& 3.00), social isolation of families (3.68 \& 3.22), parental stress and distress ( $3.06 \& 3.31)$ are the causes of child abuse in Obio/Akpor Local Government Area of Rivers State. These findings are in conformity with CFCA Resource sheet, (2016) which noted that certain factors and circumstances predispose child(ren) to either, physical, emotional or sexual abuse.Such factors include excessive flogging, disabilities, poverty, violence of parent among others.

Research Question 3; What are the functions of Librarian in Child Abuse Sensitization in Obio/Akpor Local Government Area of Rivers State?

Table 4 presents the librarians' response on the functions of Librariansin Child Abuse Sensitization in Obio/Akpor Local Government Area of Rivers State. The mean responses show that functions of librarians is to; disseminate research information to social services (3.35 \& 3.60), promoting awareness of child abuse by recommending novels ( $3.40 \& 3.39$ ), enhance supply of child abuse literatures in schools (3.38 \& 3.29), enhance the publication articles on child abuse (3.20 \& 3.37), develop programmes on child abuse and its prevention ( $3.34 \& 3.49)$, utilize library media on child abuse awareness ( $3.33 \& 3.50)$, inform the communities about issues of child abuse (3.09 \& 3.24), categorizes, prepare, and catalog materials on child abuse for easy access $(3.11 \&$ 3.58), facilitate and promote reading clubs to promote awareness of child abuse (3.15 \& 3.34),report/advocate for child abuse cases ( $3.20 \& 3.39)$, assemble and index databases of library materials on child abuse (3.24 \& 3.40). The result of this research question is in line with Itsekor (2011) who observed that librarians acquire and organize information resources for different categories of users and since they are constantly abreast with the information resources they are always readily available to assist patrons with the required information and this role is not exclusive for child abuse sensitization. 
Table 3: Functions ofLibrariansin Child Abuse Sensitization in Obi/Akpor Local Government Area of Rivers State

\begin{tabular}{|c|c|c|c|c|c|c|c|}
\hline \multirow[b]{2}{*}{$\begin{array}{l}\mathbf{S} / \\
\mathbf{N}\end{array}$} & \multirow[b]{2}{*}{ Items } & \multicolumn{3}{|c|}{ Male librarian } & \multicolumn{3}{|c|}{ Female librarian } \\
\hline & & $\bar{x}$ & S.D & Remarks & $\bar{x}$ & S.D & Remarks \\
\hline 1 & $\begin{array}{l}\text { Disseminate research } \\
\text { information to social services }\end{array}$ & 3.35 & 1.06 & Agreed & 3.60 & 0.82 & Agreed \\
\hline 2 & $\begin{array}{l}\text { Promoting awareness of child } \\
\text { abuse by recommending novels }\end{array}$ & 3.40 & 0.70 & Agreed & 3.39 & 0.71 & Agreed \\
\hline 3 & $\begin{array}{l}\text { Enhance supply of child abuse } \\
\text { literatures in schools }\end{array}$ & 3.38 & 0.90 & Agreed & 3.29 & 0.54 & Agreed \\
\hline 4 & $\begin{array}{l}\text { Enhance the publication articles } \\
\text { on child abuse }\end{array}$ & 3.20 & 0.72 & Agreed & 3.37 & 0.81 & Agreed \\
\hline 5 & $\begin{array}{l}\text { Develop programmes on child } \\
\text { abuse and its prevention }\end{array}$ & 3.34 & 1.08 & Agreed & 3.49 & 0.77 & Agreed \\
\hline 6 & $\begin{array}{l}\text { Utilize library media on child } \\
\text { abuse awareness }\end{array}$ & 3.33 & 0.89 & Agreed & 3.50 & 0.62 & Agreed \\
\hline 7 & $\begin{array}{l}\text { Inform the communities about } \\
\text { issues of child abuse }\end{array}$ & 3.09 & 0.92 & Agreed & 3.24 & 0.51 & Agreed \\
\hline 8 & $\begin{array}{l}\text { Categorizes, prepare, } \\
\text { and catalog materials on child } \\
\text { abuse for easy access }\end{array}$ & 3.11 & 0.80 & Agreed & 3.58 & 0.82 & Agreed \\
\hline 9 & $\begin{array}{l}\text { Facilitate and promote reading } \\
\text { clubs to promote awareness of } \\
\text { child abuse }\end{array}$ & 3.15 & 0.79 & Agreed & 3.34 & 0.74 & Agreed \\
\hline 10 & $\begin{array}{l}\text { Report/advocate for child abuse } \\
\text { cases }\end{array}$ & 3.20 & 0.80 & Agreed & 3.39 & 0.83 & Agreed \\
\hline \multirow[t]{2}{*}{11} & $\begin{array}{l}\text { Assemble and index databases of } \\
\text { library materials on child abuse }\end{array}$ & 3.24 & 0.82 & Agreed & 3.40 & 0.81 & Agreed \\
\hline & Grand Mean \& S.D & 3.25 & 0.86 & & 3.42 & 0.73 & \\
\hline
\end{tabular}

Field Survey 2019

Research Question 4; What are the preventive measures to curb Child Abuse in Obio/Akpor Local Government Area of Rivers State?

Table 3: Preventive measures to curb Child Abuse in Obio/Akpor Local Government Area of Rivers State

\begin{tabular}{|c|c|c|c|c|c|c|c|}
\hline \multirow[b]{2}{*}{$\begin{array}{l}\mathbf{S} / \\
\mathbf{N}\end{array}$} & \multirow[b]{2}{*}{ Items } & \multicolumn{2}{|c|}{ Male librarian } & \multicolumn{4}{|c|}{ Female librarian } \\
\hline & & $x$ & S.D & Remarks & $\boldsymbol{x}$ & S.D & Remarks \\
\hline 1 & $\begin{array}{l}\text { Educate parents and children } \\
\text { about child abuse through } \\
\text { promotion of reading culture in } \\
\text { the library }\end{array}$ & 3.43 & 0.70 & Agreed & 3.16 & 0.79 & Agreed \\
\hline 2 & $\begin{array}{l}\text { Improve positive parenting } \\
\text { through circulating related } \\
\text { literature }\end{array}$ & 3.27 & 0.87 & Agreed & 3.31 & 0.87 & Agreed \\
\hline 3 & $\begin{array}{l}\text { Provide community based } \\
\text { reading activities on preventing } \\
\text { child abuse }\end{array}$ & 3.56 & 0.69 & Agreed & 3.23 & 0.85 & Agreed \\
\hline 4 & $\begin{array}{l}\text { Encourage public policies and } \\
\text { programs that will prevent child } \\
\text { abuse. }\end{array}$ & 3.33 & 0.90 & Agreed & 3.56 & 1.09 & Agreed \\
\hline 6 & $\begin{array}{l}\text { Address signs of abuse } \\
\text { promptly }\end{array}$ & 3.51 & 0.82 & Agreed & 3.44 & 0.80 & Agreed \\
\hline 7 & $\begin{array}{l}\text { Make databases of library } \\
\text { materials on child abuse } \\
\text { available to the public }\end{array}$ & 3.19 & 0.89 & Agreed & 3.39 & 0.86 & Agreed \\
\hline \multirow[t]{2}{*}{8} & $\begin{array}{l}\text { Use media interventions to } \\
\text { discourage child abuse }\end{array}$ & 3.20 & 0.72 & Agreed & 3.40 & 1.06 & Agreed \\
\hline & Grand Mean \& S.D & 3.36 & 0.80 & & 3.36 & 0.90 & \\
\hline
\end{tabular}

Field Survey 2019 
Table 4 presents Preventive measures to curb Child Abuse in Obio/Akpor Local Government Area of Rivers State. The mean values of each item represented on the table shows that the listed items were agreed by the respondents: educate parents and children about child abuse through reading culture in the library $(3.43 \& 3.16)$, improve positive parenting through reading related literature $(3.27 \& 3.31)$, provide community based reading activities on preventing child abuse $(3.56 \& 3.23)$,encourage public policies and programs that will prevent child abuse(3.33 \& 3.56),address signs of abuse promptly(3.51 \& 3.44), make databases of library materials on child abuse available to the public (3.19 \& 3.39), use media interventions to discourage child abuse (3.20\&3.40). The result agree with Factsheet (2018) that there are protective factors that may help to lower the risk of child abuse, these are nurturing and attachment, knowledge and parenting and of child and youth development, parental resilience and social connections. Hardcastle, Mark, Hughes and Sethi (2010) also has it that home visitation programmes, positive parenting programmes, school-based programmes to train children to recognize sexual and other abuse, gathering and using data and intelligence from health personnel and other agencies also help in the prevention of child abuse.

\section{Hypothesis 1}

There is no significance difference in the mean response of male and female librarian on the functions of Librarian on Child Abuse Sensitization in Obio/Akpor Local Government Area of Rivers State.

Table 5: Z-test analysis on the mean response of male and female librarian on the functions of Librarian on Child Abuse Sensitization.

\begin{tabular}{llllllll}
\hline Groups & Mean & S.D & N & Lev. of sig. & z-cal & z-crit & Decision \\
\hline Male & 3.25 & 0.86 & 16 & & & \\
& & & & 0.05 & 0.59 & 1.96 & Accepted \\
Female & 3.42 & 0.73 & 16 & & & \\
\hline
\end{tabular}

Table 5 presents the z-test analysis on the mean response of male and female $\mathrm{s}$ on the functions of Librarians in Child Abuse Sensitization. Based on the fact that the null hypothesis is accepted if the z-cal is lower than the $z$ crit. Since the z-cal on the table is less than the z-critical the null hypothesis is therefore accepted.

\section{Conclusion}

Based on the result of the findings, the researcher concludes as follows.

- It was found that flogging/beating, denial of clothes, denial of school fees,denial of food, hawking, sexual abuse, verbal abuse, work in factories, denial of books, coercion into early marriage, unpleasant touches are forms of child abuse in the society.

- Also from research question two, it was concluded that disabilities, death of parents, poverty, unemployment, drunken parents, violent parents, low education, poorneighborhood,social isolation of families, parental stress and distress are the causes of child abuse in Obio/Akpor Local Government Area of Rivers State.

- From research question three, the researcher concludes that dissemination of research information to social services, promotion of awareness of child abuse by recommending novels, enhancement of supply of child abuse literatures in schools, enhancement of the publication articles on child abuse, development of programmes on child abuse and its prevention, utilization of library media on child abuse awareness, information of the communities about issues of child abuse, categorization, preparation, and cataloguing of materials on child abuse for easy access, facilitation and promotion of reading clubs to promote awareness of child abuse, reporting and advocating for child abuse cases, assembling and indexing databases of library materials on child abuse are the functions of librarians inchild abuse sensitization in Obio/Akpor Local Government Area of Rivers State.

- Finally, it was found that educating parents and children about child abuse through reading culture in the library, improving positive parenting through reading related literature, providingcommunity based reading activities on preventing child abuse, encouragingpublic policies and programs that will prevent 
child abuse,addressing signs of abuse promptly, making databases of library materials on child abuse available to the public and using media interventions to discourage child abuse are possible preventive measures for child abuse.

\section{Recommendations}

The following recommendations were made based on the findings of the study.

- Librarians should contribute to solving the predicaments of child abuse by the utilization of library holdings for awareness and sensitization.

- Parents should also cultivate the habit of accessing the library for relevant materials that may sensitize them on how to prevent their wards from any form of abuse.

- While the librarians helps in the gathering and arrangement of information, human rights advocates, caregivers and community development agents in gender vanguards should encourage them by accessing the library for vital information.

\section{References}

AFRUCA (2013). Africans Unite Against Child Abuse Promoting the Rights and Welfare of African Children. Also available at https://www.afruca.org/wp-content/uploads/2013/06/SACUS01_what-is-childabuse.pdf

Badoe, E (2017). A Critical Review of Child Abuse and its Management in Africa. African Journal of Emergency Medicine 7(supp):532-535

Brophy, P (2007). The Library in the Twenty-first Century, 2nd edition. London facet

CFCA Resource Sheet (2016). What is Child Abuse and Neglect. Also Available at https://aifs.gov.au/cfca/publications/what-child-abuse-and-neglect

Ede, V.I \&Kalu D.Z (2018). Child Abuse in Nigeria:Responses of Christian Churches and the way out. International Journal for Innovative Research in Multidisciplinary Field 4(4): 46-53.

Factsheet (2018). Preventing Child Abuse and Neglect: Children Bureau. Child Welfare Information Gateway.Also available at http://www.childwelfare.gov.

Government of Netherlands.Strategies for preventing child abuse. Also available at https://www.government.nl/topics/child-abuse/strategy-against-child-abuse/preventing-and-identifyingsigns-of-child-abuse

Gupta, N \& Aggarwal, N.K (2012). Child Abuse: Forensic Psychiatric. Delhi Psychiatric Journal 15(2): $416-419$

Hardcastle, K.A., Mark A.B.,, Hughes, K.\&Sethi, D. (2010). Implementing Child Maltreatment Prevention Programmes: What the experts say. Centre for Public Health. World Health Organization Europe.

Itsekor, V.O (2012). The Role of Librarians in the Development of Education in Nigeria. Project Centre for Learning Resources Covenant University Ota, Nigeria.

Mcgill University Research in Scutti (2015). Neglect may be harmful as a slap to a child: Emotional Abuse has real consequences. Medical Daily. Also available https://www.medicaldaily.com/neglect-may-beharmful-slap-child-emotional-abuse-has-real-consequences-357164.

Ministry of Social Welfare, Gender and Children's Affairs Sierra Leone (2009).Dealing |with Child Abuse; A Handbook for Child Welfare Workers in Sierra Leone

National Centre for Victims of Crimes (2011). Sexual Abuse Statistics. Also Available at https://victimsofcrime.org/media/reporting-on-child-sexual-abuse/child-sexual-abuse-statistics

Nordqvist, C (2018)Recognizing child abuse.Newsletter, Medical News Today. Also available at https://www.medicalnewstoday.com/articles/241532.php

Olok-Ake, A (2000). Protecting the Children in the Midst of Conflict, Local, National and Regional Initiatives. Proceedings of the Conference on War affected Children in the West Africa Accra Ghana.

Onwe, S.O (2014). Championing the campaign against Child Abuse in Nigeria; A call to save the needy.International Journal of Humanities and Social Sciences 4,(1) 279-283

W.H.O (1999): Report of the consultation of Child Abuse Prevention; Geneva 1999. Also available at http://www.who.int/violence_injury prevention/violence/neglect/en/.

W.H.O (2006) Child abuse and neglect by parents and other caregivers https:/www.who.int/violence_injury_prevention/violence/global_campaign/en/chap3.pdf. 